\title{
MOG antibody seropositivity in a patient with encephalitis: beyond the classical syndrome
}

\author{
Sara Mariotto ${ }^{1,2^{*}} \mathbb{D}$, Salvatore Monaco ${ }^{1}$, Patrick Peschl ${ }^{2}$, Ilaria Coledan ${ }^{3}$, Romualdo Mazzi ${ }^{3}$, Romana Höftberger ${ }^{4}$, \\ Markus Reindl ${ }^{2}$ and Sergio Ferrari ${ }^{1}$
}

\begin{abstract}
Background: The presence of circulating anti-myelin oligodendrocyte glycoprotein antibodies (MOG-Abs) has been described in sera of patients with different inflammatory conditions of the central nervous system. In adults the core clinical feature is usually characterised by acute myelitis and/or optic neuritis. We here report an atypical case with serum and cerebrospinal fluid MOG-Abs and a clinical picture suggestive for acute encephalitis.

Case presentation: A 31-year-old Indian man presented with altered mental status, slight fever, and ataxia. Brain magnetic resonance imaging noted a widespread involvement of the white matter associated with slight cortical and subcortical damage in absence of contrast enhancement. An extensive infectious screening resulted negative while autoimmune analysis revealed the presence of MOG-Abs, detected with live cell-based assay. After treatment with intravenous immunoglobulins a marked and prompt clinical and radiological improvement was observed.

Conclusions: To date, several areas of uncertainty still remain regarding clinical features and prognosis of subjects with MOG-Abs. The description of atypical cases is crucial, since recognition of this condition leads to prompt treatment and better prognosis, as in the case here reported.
\end{abstract}

Keywords: Autoimmune diseases, Encephalitis, Anti-myelin oligodendrocyte glycoprotein antibodies (MOG-abs)

\section{Background}

Anti-myelin oligodendrocyte glycoprotein antibodies (MOG-Abs) have been reported in different inflammatory demyelinating diseases as acute disseminated encephalomyelitis (ADEM), neuromyelitis optica spectrum disorders (NMOSD), idiopathic optic neuritis, idiopathic myelitis, and atypical multiple sclerosis [1-13]. However, the whole spectrum of clinical phenotypes associated with MOG-Abs-related disorders has still to be clearly defined. Here, we present a patient with MOG-Abs and a clinical picture resembling infectious encephalitis as a possible new clinical phenotype associated with these antibodies.

\footnotetext{
* Correspondence: sara.mariotto@gmail.com

'Department of Neuroscience, Biomedicine and Movement Sciences, Section of Neurology, University of Verona, Verona, Italy

${ }^{2}$ Clinical Department of Neurology, Medical University of Innsbruck,

Innsbruck, Austria

Full list of author information is available at the end of the article
}

\section{Case presentation}

A previously healthy 31-year-old Indian man presented to the emergency room with confusion and altered consciousness. Five days prior to onset of neurological symptoms he developed slight fever $\left(<38^{\circ} \mathrm{C}\right)$, sore throat and headache. His past medical history was unremarkable except for a recent stay in India for 2 months. Neurological examination disclosed a wide-based and unsteady gait and reduced level of consciousness. Diffuse papules and enanthema were also observed and spontaneously disappeared few days later. A slight increase of erythrocyte and leukocyte cell counts (13.000 cells/ $\mu \mathrm{L})$, erythrocyte sedimentation rate $(30 \mathrm{~mm} / \mathrm{h})$ and C-reactive protein $(48 \mathrm{mg} / \mathrm{l})$ was noted on basic laboratory test. The patient was initially treated with acyclovir and ceftriaxone for a presumptive diagnosis of infectious encephalitis. A cerebrospinal fluid (CSF) analysis showed total protein 
level of $53 \mathrm{mg} / \mathrm{dl}, 179$ cells $/ \mu \mathrm{L}$ (90\% mononuclear) in absence of oligoclonal IgG bands. On brain magnetic resonance imaging (MRI), fluid attenuated inversion recovery (FLAIR) and T2 diffuse hyperintensities involving thalamus, basal ganglia, internal capsule, mesial temporal lobes and brainstem associated with small hyperintensities in the subcortical, periventricular and cortical regions were noted in absence of contrast enhancement (Fig. 1a-d). Diffusion weighted images showed a mild restrictive pattern of the sopratentorial lesions affecting the left and right thalamus, the posterior limb of the internal capsule of both sides, the splenium and the posterior profile of the left trigonum. These lesions also presented medium-high apparent diffusion coefficient values and central core of low apparent diffusion coefficient, suggesting an inflammatory process. Whole spinal cord MRI was normal. A comprehensive workup for viral encephalitis and atypical infections including polymerase chain reaction for Human immunodeficiency virus, Enterovirus, Herpes simplex 1-2-6, Epstein-Barr, Cytomegalovirus, Varicella Zoster, Toxoplasma, Mycobacterium tuberculosis, Treponema pallidum, Bartonella henselae, Human Parechovirus, West Nile, Dengue, Chikungunya, and Japanese encephalitis resulted negative and also cultures for bacteria and fungi. An extensive autoimmune screening including anti-nuclear antibodies, complement levels, thyroid function and antibodies, autoantibodies to synaptic receptors and neuronal cell surface proteins was also negative. The criteria for collagen diseases, vasculitis, Behçet and Hashimoto encephalopathy were not satisfied. No neuropil staining was observed on tissue-based screening with immunohistochemistry on rat sections. Testing for MOG-Abs with a live cellbased assay with recombinant full-length MOG expressed in HEK293 cells [14], identified MOG-Abs both in the serum (titer of 1:5120) and in the CSF (titer 1:8). Staining of rat brain tissue with serum and CSF samples resulted in a specific myelin staining already described for MOG-Abs as shown in Fig. 2 [15]. The patient was treated with intravenous immunoglobulin (IVIg) $0.5 \mathrm{~g} / \mathrm{kg} /$ day for 5 days with an almost complete clinical recovery in a few days. On control MRI examination after 2 weeks a dramatic improvement of pre-existing lesion was observed (Fig. 1e-h). Only the persistence of slight unsteady gait was noted at the last clinical evaluation 2 weeks after the onset.

\section{Discussion and conclusions}

We here report an atypical presentation of MOG-Abs associated disorder with a prompt response to IVIg which satisfied the criteria of "possible encephalitis of presumed infectious origin" which also was the main presumptive clinical diagnosis [16]. Since the patient
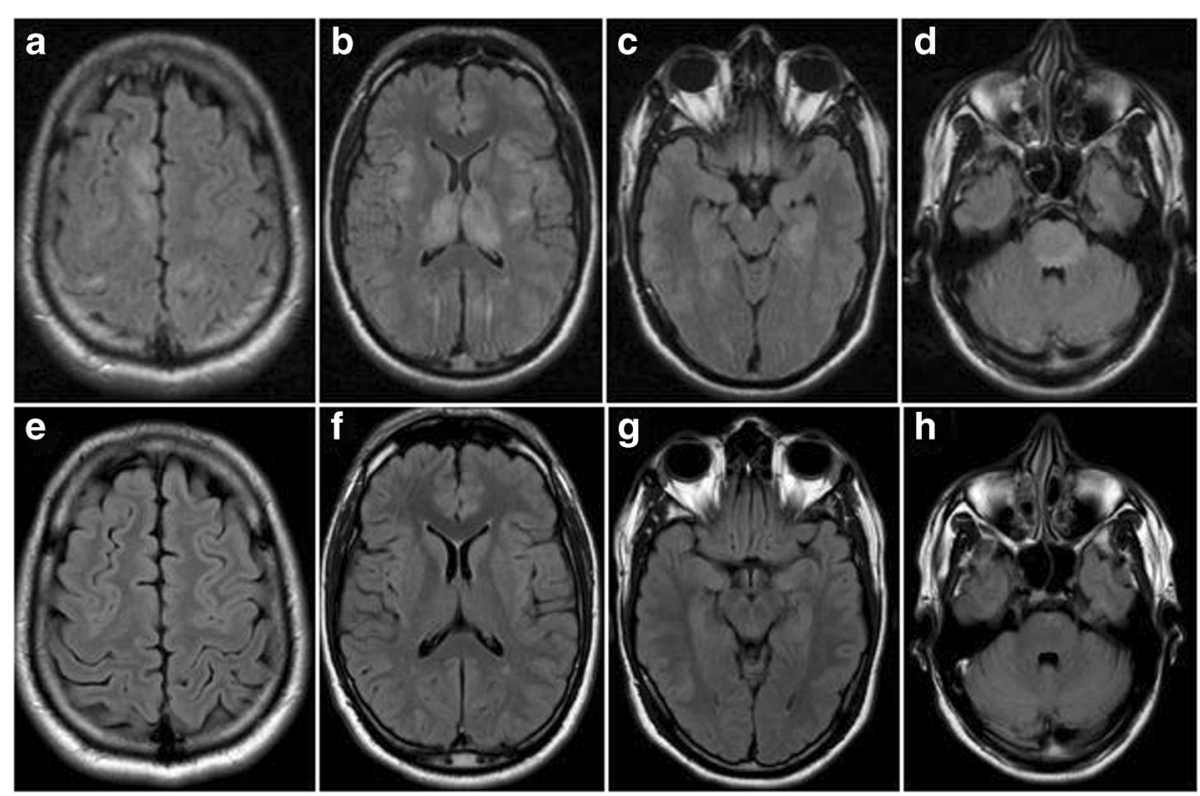

Fig. 1 FLAIR sequence from the brain MRI at onset (a-d) and after treatment (e-h). Cortical and subcortical damage (a-b) with severe bilateral involvement of thalamus and internal capsule (b), mesial temporal lobes (c) and pons (d) in absence of contrast enhancement, is seen on brain MRI performed ad onset. After treatment with IVIg a significant improvement was noted with an almost complete resolution of the cortical, thalamic and basal ganglia involvement (e-f) and a reduction of temporal $(\mathbf{g})$ and brainstem lesions $(\mathbf{h})$ 


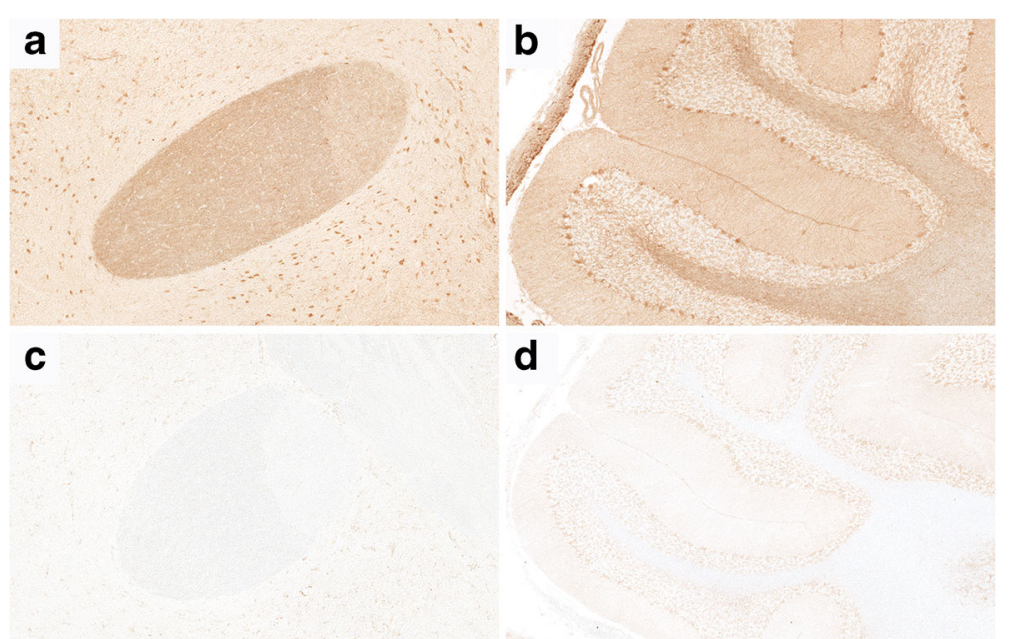

Fig. 2 Immunohistochemical analysis. Serum (dilution 1:100, MOG-lgG and IgG1 titer 1:5120, also reactive with rat and mouse MOG) and CSF (dilution 1:2, MOG-ab titer 1:8) samples were screened by immunohistochemistry on a tissue-based assay (in-house; avidin-biotin-peroxidase technique; rat brain) as described previously by Sepulveda et al. 2016 [15]. The CSF (diluted 1:2) showed a specific myelin staining in the anterior commissure $(\mathbf{a})$ and cerebellar white matter $(\mathbf{b})$, whereas a control sample was negative $(\mathbf{c}$, d). Magnification: A, C: $\times 100 ; B, D: \times 60$

presented with subacute onset of altered mental status, new focal central nervous system findings and CSF pleocytosis in absence of alternative causes, he also met the revised diagnostic criteria for possible autoimmune encephalitis recently proposed [17]. However, the absence of neuropil staining on immunohistochemistry ruled out the presence of other well defined auto-antibodies or overlapping syndromes. In the case here reported, some features, as the multiple sopratentorial lesions of the white matter, basal ganglia, thalamus and brainstem, resemble those observed in ADEM. However, pleocytosis was higher than that usually observed in patients with ADEM and MRI was not totally compatible due to the type of gray and periventricular involvement and the absence of spinal cord lesions. Since criteria for ADEM have been clearly established only for pediatric cases [18] and the diagnosis in adults, also with MOG-Abs, remain challenging [17], we classified the case as "encephalitis" rather than ADEM.

Only five cases of encephalitis with MOG-Abs have been reported so far and are summarized in Table 1 $[19,20]$.

In these reports an autoimmune aetiology was the main presumptive diagnosis while in the case here described clinical and radiological data were suggestive of an infectious process. Moreover, all the previously reported cases presented seizures at onset or during the course of the disease and 3 out of 5 patients had optic neuritis, a feature clearly associated with MOG-Abs. The radiological features here described are also unique and in part different from the ADEM-like [19] or unilateral cortical lesions [20] previously reported. In these cases the onset was characterised by an exclusive cortical damage and in only one patient the involvement of corpus callosum, cingulate gyrus, frontal lobes, midbrain, thalamus, and nucleus basalis was noted during the follow-up [19]. In our patient we observed at onset an extensive involvement of the thalamus, basal ganglia, internal capsule, mesial temporal lobes and brainstem associated with subcortical, periventricular and cortical damage. Finally, the prompt response to IVIg is also a peculiar finding, since the other cases had a complete recovery after steroids treatment that led to the definition of "steroid- responsive encephalitis "[20]. The role of infectious agent in triggering MOG-Abs production is still a matter of debate. However, the flu-like symptoms here reported are not unexpected since attacks are preceded by infections at least once in about $40 \%$ of MOG-Abs positive cases [1]. The infection could also be responsible for the blood-brain barrier breakdown that allows the entry of autoantibodies in the central nervous system. This report confirms that MOG-Abs might denote a disease entity in its own right and that the spectrum of MOG-Abs associated diseases is wider than NMOSD and ADEM. Since a prompt and adequate treatment can lead to a favorable outcome, clinicians should be aware of this condition, also in clinical pictures suggestive for infectious encephalitis. 


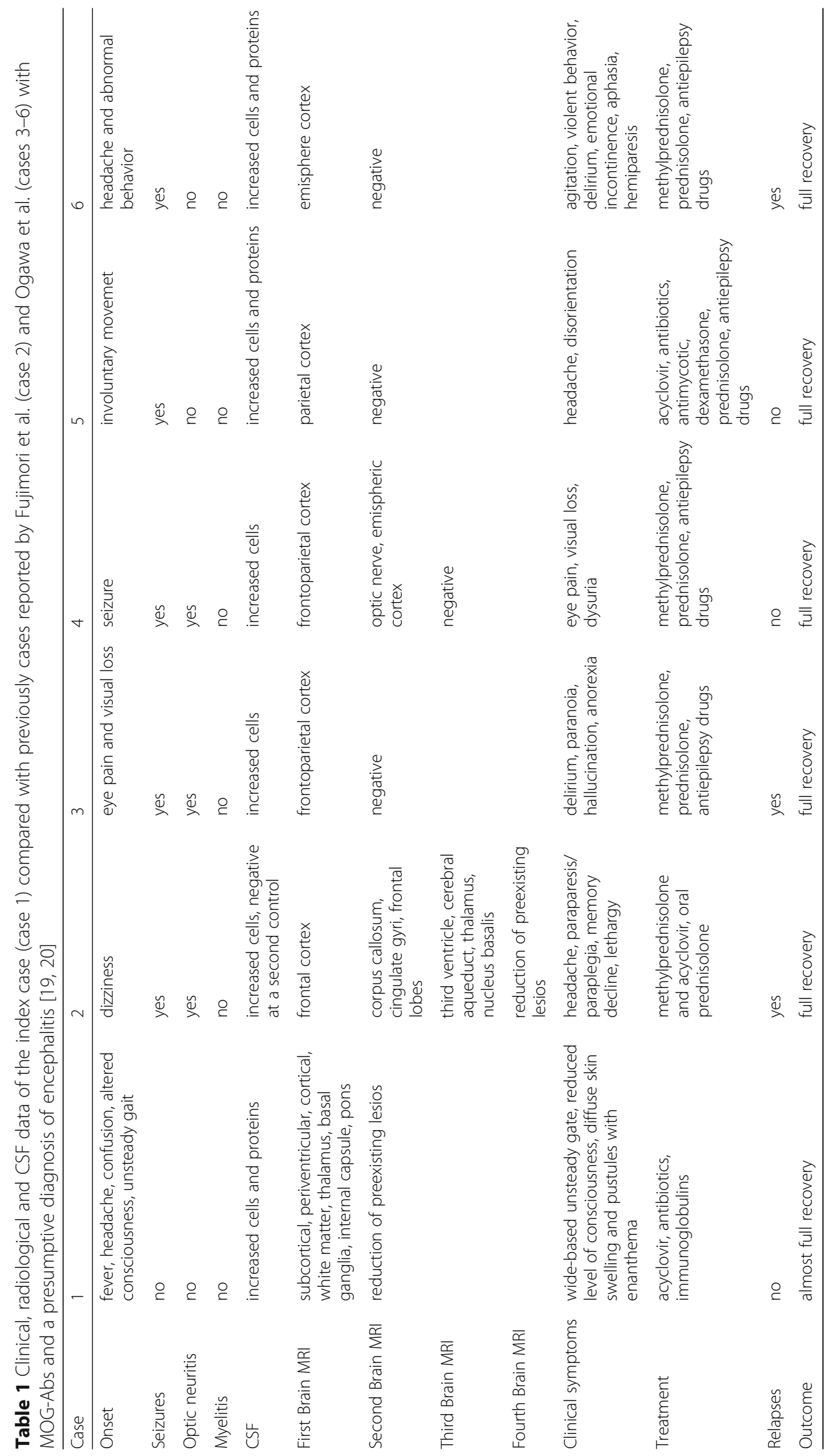




\section{Abbreviations}

ADEM: Acute disseminated encephalomyelitis; CSF: Cerebrospinal fluid; FLAIR: Fluid attenuated inversion recovery; IVIg: Immunoglobulin; MOG-Abs: Anti-myelin oligodendrocyte glycoprotein antibodies; MRI: Magnetic resonance imaging; NMOSD: Neuromyelitis optica spectrum disorders

\section{Acknowledgements}

The authors thank Daniela Alberti, Alessia Farinazzo (Department of Neuroscience, Biomedicine and Movement, Section of Neurology, University of Verona, Italy), and Kathrin Schanda (Clinical Department of Neurology, Medical University of Innsbruck, Innsbruck, Austria) for their technical assistance.

\section{Funding}

Sara Mariotto is currently supported by a research fellowship of the European Academy of Neurology. Patrick Peschl and Markus Reindl are supported by a research Grant from the Fonds zur Förderung der wissenschaftlichen Forschung, Austria (FWF graduate program W1206 SPIN). This study was supported by a research grant from the Austrian Federal Ministry of Science and Economy (grant BIG WIG MS, Markus Reindl).

\section{Availability of data and materials}

All data generated or analysed during this study are included in this published article.

\section{Authors' contributions}

SMa: study design, analysis and interpretation of patient data, drafting the manuscript. SMo: revising the manuscript for content, study supervision. PP: analysis and interpretation of cell-based assay. IC: analysis and interpretation of patient data regarding the infectious origin. RM: analysis and interpretation of patient data regarding the infectious origin $\mathrm{RH}$ : analysis and interpretation of histological data. MR: analysis and interpretation of data, study design, revising the manuscript for content, study supervision. SF: analysis and interpretation of data, study design, revising the manuscript for content, study supervision. All authors read and approved the final manuscript.

\section{Ethics approval and consent to participate} Not applicable.

\section{Consent for publication}

written informed consent was obtained from the patient for publication of this Case Report and any accompanying images. A copy of the written consent is available for review by the Editor of this journal.

\section{Competing interests}

M. Reindl is an academic editor for PLoS One, The University Hospital, and Medical University of Innsbruck (Austria, Markus Reindl); receives payments for antibody assays (NMDAR, AQP4, and other autoantibodies) and for MOG and AQP4 antibody validation experiments organized by Euroimmun (Luebeck, Germany). The other authors report no competing interests.

\section{Publisher's Note}

Springer Nature remains neutral with regard to jurisdictional claims in published maps and institutional affiliations.

\section{Author details}

'Department of Neuroscience, Biomedicine and Movement Sciences, Section of Neurology, University of Verona, Verona, Italy. ${ }^{2}$ Clinical Department of Neurology, Medical University of Innsbruck, Innsbruck, Austria. ${ }^{3}$ Department of Diagnostics and Public Health, Section of Infectious Diseases, University of Verona, Verona, Italy. ${ }^{4}$ Institute of Neurology, Medical University of Vienna, Vienna, Austria.
Received: 5 July 2017 Accepted: 27 September 2017

Published online: 05 October 2017

\section{References}

1. Jarius S, Ruprecht K, Kleiter I, Borisow N, Asgari N, Pitarokoili K, Pache F, Stich O, Beume LA, Hümmert MW, Ringelstein M, Trebst C, Winkelmann A, Schwarz A, Buttmann M, Zimmermann H, Kuchling J, Franciotta D, Capobianco M, Siebert E, Lukas C, Korporal-Kuhnke M, Haas J, Fechner K, Brandt AU, Schanda K, Aktas O, Paul F, Reindl M, Wildemann B. in cooperation with the Neuromyelitis Optica Study Group (NEMOS) MOG-IgG in NMO and related disorders: a multicenter study of 50 patients. Part 2: Epidemiology, clinical presentation, radiological and laboratory features, treatment responses, and long-term outcome. J Neuroinflammation. 2016;13:280.

2. Brilot F, Dale RC, Selter RC, Grummel V, Kalluri SR, Aslam M, Busch V, Zhou D, Cepok S, Hemmer B. Antibodies to native myelin oligodendrocyte glycoprotein in children with inflammatory demyelinating central nervous system disease. Ann Neurol. 2009;66:833-42.

3. Pröbstel AK, Dornmair K, Bittner R, Sperl P, Jenne D, Magalhaes S, Villalobos A, Breithaupt C, Weissert R, Jacob U, Krumbholz M, Kuempfel T, Blaschek A, Stark W, Gärtner J, Pohl D, Rostasy K, Weber F, Forne I, Khademi M, Olsson T, Brilot F, Tantsis E, Dale RC, Wekerle H, Hohlfeld R, Banwell B, Bar-Or A, Meinl E. Derfuss Antibodies to MOG are transient in childhood acute disseminated encephalomyelitis. Neurology. 2011;77:580-8.

4. Sato DK, Callegaro D, Lana-Peixoto MA, Waters PJ, de Haidar Jorge FM, Takahashi T, Nakashima I, Apostolos-Pereira SL, Talim N, Simm RF, Lino AM, Misu T, Leite MI, Aoki M, Fujihara K. Distinction between MOG antibodypositive and AQP4 antibody-positive NMO spectrum disorders. Neurology. 2014:82:474-81.

5. Spadaro M, Gerdes LA, Mayer MC, Ertl-Wagner B, Laurent S, Krumbholz M, Breithaupt C, Högen T, Straube A, Giese A, Hohlfeld R, Lassmann H, Meinl E Kümpfel T. Histopathology and clinical course of MOG-antibody-associated encephalomyelitis. Ann Clin Transl Neurol. 2015;2:295-301.

6. Pröbstel AK, Rudolf G, Dornmair K, Collonques N, Chanson JB, Sanderson NS, Lindberg RL, Kappos L, de Seze J, Derfuss T. Anti-MOG antibodies are present in a subgroup of patients with a neuromyelitis optica phenotype. J Neuroinflammation. 2015;12:46

7. Waters $P$, Woodhall M, O'Connor KC, Reindl M, Lang B, Sato DK, Juryńczyk M, Tackley G, Rocha J, Takahashi T, Misu T, Nakashima I, Palace J, Fujihara K, Leite MI, Vincent A. MOG cell-based assay detects non-MS patients with inflammatory neurologic disease. Neurol Neuroimmunol Neuroinflamm. 2015;2:e89.

8. Baumann M, Hennes EM, Schanda K, Karenfort M, Kornek B, Seidl R, Diepold K, Lauffer H, Marquardt I, Strautmanis J, Syrbe S, Vieker S, Höftberger R, Reindl M, Rostásy K. Children with multiphasic disseminated encephalomyelitis and antibodies to the myelin oligodendrocyte glycoprotein (MOG): Extending the spectrum of MOG antibody positive diseases. Mult Scler. 2016;22:1821-9.

9. Van Pelt ED, Wong YY, Ketelslegers IA, Hamann D, Hintzen RQ. Neuromyelitis optica spectrum disorders: comparison of clinical and magnetic resonance imaging characteristics of AQP4-lgG versus MOG-lgG seropositive cases in the Netherlands. Eur J Neurol. 2016;23:580-7.

10. Siritho S, Sato DK, Kaneko K, Fujihara K, Prayoonwiwat N. The clinical spectrum associated with myelin oligodendrocyte glycoprotein antibodies (anti-MOG-Ab) in Thai patients. Mult Scler. 2016;22:964-8.

11. Spadaro M, Gerdes LA, Krumbholz M, Ertl-Wagner B, Thaler FS, Schuh E, Metz I, Blaschek A, Dick A, Brück W, Hohlfeld R, Meinl E, Kümpfel T. Autoantibodies to MOG in a distinct subgroup of adult multiple sclerosis. Neurol Neuroimmunol Neuroinflamm. 2016;3:e257.

12. Lechner C, Baumann M, Hennes EM, Schanda K, Marquard K, Karenfort M, Leiz S, Pohl D, Venkateswaran S, Pritsch M, Koch J, Schimmel M, Häusler M, Klein A, Blaschek A, Thiels C, Lücke T, Gruber-Sedlmayr U, Kornek B, Hahn A, Leypoldt F, Sandrieser T, Gallwitz H, Stoffels J, Korenke C, Reindl M, Rostásy K. Antibodies to MOG and AQP4 in children with neuromyelitis optica and limited forms of the disease. J Neurol Neurosurg Psychiatry. 2016;87:897-905.

13. Hacohen $Y$, Mankad K, Chong WK, Barkhof F, Vincent A, Lim M Wassmer E, Ciccarelli O, Hemingway C. Diagnostic algorithm for relapsing acquired demyelinating syndromes in children. Neurology. 2017; doi:10.1212/WNL.0000000000004117.

14. Di Pauli F, Mader S, Rostasy K, Schanda K, Bajer-Kornek B, Ehling R, Deisenhammer F, Reindl M, Berger T. Temporal dynamics of anti-MOG antibodies in CNS demyelinating diseases. Clin Immunol. 2011;138:247-54. 
15. Sepúlveda M, Armangue T, Martinez-Hernandez E, Arrambide G, Sola-Valls N, Sabater L, Téllez N, Midaglia L, Arino H, Peschl P, Reindl M, Rovira A Montalban X, Blanco Y, Dalmau J, Graus F, Saiz A. Clinical spectrum associated with MOG autoimmunity in adults: significance of sharing rodent MOG epitopes. J Neurol. 2016;263:1349-60.

16. Venkatesan A, Tunkel AR, Bloch KC, Lauring AS, Sejvar J, Bitnun A, Stahl JP, Mailles A, Drebot M, Rupprecht CE, Yoder J, Cope JR, Wilson MR, Whitley RJ, Sullivan J, Granerod J, Jones C, Eastwood K, Ward KN, Durrheim DN, Solbrig MV, Guo-Dong L, Glaser CA, International Encephalitis Consortium. Case definitions, diagnostic algorithms, and priorities in encephalitis: consensus statement of the international encephalitis consortium. Clin Infect Dis. 2013; 57:1114-28.

17. Graus F, Titulaer MJ, Balu R, Benseler S, Bien CG, Cellucci T, Cortese I, Dale RC, Gelfand JM, Geschwind M, Glaser CA, Honnorat J, Höftberger R, lizuka T, Irani SR, Lancaster E, Leypoldt F, Prüss H, Rae-Grant A, Reindl M, Rosenfeld MR, Rostásy K, Saiz A, Venkatesan A, Vincent A, Wandinger KP, Waters P, Dalmau J. A clinical approach to diagnosis of autoimmune encephalitis. Lancet Neurol. 2016;15:391-404.

18. Krupp LB, Tardieu M, Amato MP, Banwell B, Chitnis T, Dale RC, Ghezzi A, Hintzen R, Kornberg A, Pohl D, Rostasy K, Tenenbaum S, Wassmer E. International Pediatric Multiple Sclerosis Study Group criteria for pediatric multiple sclerosis and immune-mediated central nervous system demyelinating disorders: revisions to the 2007 definitions. Mult Scler. 2013 19:1261-7.

19. Fujimori J, Takai Y, Nakashima I, Sato DK, Takahashi T, Kaneko K, Nishiyama S, Watanabe M, Tanji H, Kobayashi M, Misu T, Aoki M, Fujihara K. Bilateral frontal cortex encephalitis and paraparesis in a patient with anti-MOG antibodies. J Neurol Neurosurg Psychiatry. 2017:88:534-6.

20. Ogawa R, Nakashima I, Takahashi T, Kaneko K, Akaishi T, Takai Y, Sato DK, Nishiyama S, Misu T, Kuroda H, Aoki M, Fujihara K. MOG antibody-positive, benign, unilateral, cerebral cortical encephalitis with epilepsy. Neurol Neuroimmunol Neuroinflamm. 2017:4:e322.

\section{Submit your next manuscript to BioMed Central and we will help you at every step:}

- We accept pre-submission inquiries

- Our selector tool helps you to find the most relevant journal

- We provide round the clock customer support

- Convenient online submission

- Thorough peer review

- Inclusion in PubMed and all major indexing services

- Maximum visibility for your research

Submit your manuscript at www.biomedcentral.com/submit 